Journal of Development and Social Change, Vol. 3, No. 1, April 2020

p-ISSN 2614-5766, https://jurnal.uns.ac.id/jodasc

\title{
DINAMIKA KONFLIK KERUSUHAN MEI 1998 DI KOTA SURAKARTA MELALUI PERSPEKTIF KORBAN
}

\author{
Lydiana Salim ${ }^{1}$, Akhmad Ramdhon ${ }^{2}$ \\ Program Studi Sosiologi Fakultas Ilmu Sosial dan Politik \\ Universitas Sebelas Maret Surakarta Indonesia \\ Email $^{1}$ : salimlydiana@gmail.com, Email ${ }^{2}$ : wacana3000@gmail.com
}

\begin{abstract}
The May 1998 riots that occurred were the result of a collection of political, social and economic events that occurred during the New Order. Events of the May 1998 riots in the city of Surakarta had a great influence on the lives of the victims. In the aftermath of the May 1998 riots, several victims were declared traumatized to the extent of damaging their homes and businesses. The purpose of this study was to determine the chronology of the May 1998 riots and analyze the dynamics of the May 1998 riots in the city of Surakarta. The theory in this research is the Conflict theory from Ralf Dahrendorf. This type of research is a qualitative research with an ethnographic approach in the city of Surakarta. The sampling technique with snowball sampling technique. The research informants consisted of student activists and formal organizations, journalists, religious leaders and victims of the May 1998 incident. Data were collected by observation, in-depth interviews and documentation. To test data validity with source triangulation. The data analysis technique uses an interactive analysis model from Miles and Huberman. The results showed that the May 1998 riots which occurred for two days caused damage and material losses. Mass amok movements occur regularly by doing damage, looting to arson in every corner of the city. After the May 1998 riots, the city's economic sector did not work. Some entrepreneurs were forced to stop production for a while due to the damage they experienced. Post-disaster economic reconstruction is carried out by the government and community groups by providing assistance to victims. From social conditions, after the May 1998 riots some victims decided to flee to areas that were safe from conflict. After the riots of May 1998 victims were pressured by the community in the form of negative stigma. Discomfort and fear experienced by the people after the riots began to be addressed by involving religious institutions. Religious institutions work together in creating communication forums between communities. in terms of the psychological condition of the people after the riots, some victims experienced trauma from witnessing firsthand the atrocities that occurred.
\end{abstract}

Keyword: May 1998 riots, Victim, Conflict

Abstrak: Kerusuhan Mei 1998 yang terjadi merupakan hasil dari kumpulan peristiwa politik,
sosial dan ekonomi yang terjadi di masa orde baru. Perisitiwa kerusuhan Mei 1998 di Kota
Surakarta memiliki pengaruh besar terhadap kehidupan korban. Pasca kerusuhan Mei 1998
beberapa korban dinyatakan trauma hingga mengalami kerusakkan tempat tinggal dan tempat
usaha. Tujuan penelitian ini untuk mengetahui kronologi kerusuhan Mei 1998 dan
menganalisis dinamika Konflik kerusuhan Mei 1998 di kota Surakarta. Teori dalam
penelitian ini yaitu, teori Konflik dari Ralf Dahrendorf. Penelitian kualitatif dengan
pendekatan etnografi ini dilakukan di Surakarta. Teknik pengambilan sampel dengan teknik
snowball sampling. Adapun informan penelitian terdiri dari aktivis mahasiswa dan organisasi 
formal, wartawan, pemuka agama dan korban-korban peristiwa mei 1998. Data dikumpulkan dengan observasi, wawancara mendalam dan dokumentasi. Untuk menguji validitas data dengan triangulasi sumber. Teknik analisis data menggunakan model analisis interaktif dari Miles dan Huberman. Hasil penelitian menunjukkan, kerusuhan Mei 1998 yang terjadi selama dua hari menimbulkan kerusakan dan kerugian material. Gerakan amuk massa terjadi secara teratur dengan melakukan perusakan, penjarahan hingga pembakaran di setiap sudut kota. Pasca kerusuhan Mei 1998, sektor ekonomi kota tidak berjalan. Beberapa pengusaha terpaksa berhenti produksi untuk sementara waktu akibat kerusakan yang dialaminya. Rekonstruksi ekonomi pasca bencana dilakukan oleh pemerintah dan kelompok masyarakat dengan memberikan bantuan kepada korban. Dari kondisi sosial, pasca kerusuhan Mei 1998 beberapa korban memutuskan untuk mengungsi ke daerah yang aman dari konflik. Pasca kerusuhan Mei 1998 korban mendapatkan tekanan dari masyarakat berupa stigma negatif. Rasa tidak nyaman dan ketakutan yang dialami masyarakat pasca kerusuhan mulai ditangani dengan melibatkan lembaga agama. Lembaga agama bekerjasama dalam membuat forum komunikasi antar masyarakat. dari segi kondisi psikologis masyarakat pasca kerusuhan, beberapa korban mengalami trauma akibat menyaksikan secara langsung kekejaman yang terjadi.

Kata Kunci: Kerusuhan Mei 1998, Korban, Konflik

\section{PENDAHULUAN}

Realita yang terjadi sebagai bentuk untuk mempertahankan kekuasaan, pemerintah orde baru memakai cara-cara kekerasan demi menutup upaya demonstrasi massa. Selain itu, cara yang dipakai oleh pemerintah orde baru untuk melanggengkan posisinya yaitu menanamkan sifat radikalisme diantara masyarakat. penanaman radikaslisme diturunkan melalui undang-undang yang memiliki sentiment terhadap etnis dan penggambaran etnis lain oleh masyarakat seakan adalah penghianat bangsa dan. Penanaman sifat radikalisme ini cenderung berhasil karena pada saat pemerintahan orde baru terlihat sangat jelas bahwa terdapat kesenjangan sosial dan ekonomi antara penduduk pribumi dengan penduduk beretnis lain. Kesenjangan ini membangun rasa iri penduduk pribumi akan keberhasilan masyarakat etnis. Sehingga mereka merasa pantas untuk merebut apa yang dimiliki masyarakat etnis. Selain itu, orde baru juga menanamkan sifat nasionalisme dalam setiap elemen masyarakat.

Nasionalisme mendorong pengekalan sentiment rasis sementara komunitas-komunitas mencoba untuk mendefinisikan 'komunitas-komunitas terbayang' mereka sebagai terpisah, terbatas, dan berdaulat (Anderson, 2002;141). Sentiment terhadap minoritas terus dipupuk pemerintah untuk memainkan perseturuan sosial. Para elite menggambarkan kaum minoritas sebagai 'kambing hitam' untuk mengalihkan serangan masyarakat pada mereka. Massa yang frustasi akan keadaan negara dan elite politik teralihkan dengan menjadikan kaum minoritas sebagai arena pelampiasan.

Konflik yang didasari atas kesenjangan ini terus berlangsung di Kota Surakarta tanpa adanya pihak yang dapat mendamaikan keadaan. Berbagai peristiwa konflik pecah akibat rasa iri masyarakat asli kota Surakarta dengan masyarakat etnis yang berpenghasilan tinggi. ketegangan muncul dari sebuah keinginan mayoritas untuk mengesampingkan kelompok yang berada dalam posisi kekuatan ekonomi. Sehingga dalam beberapa kurun waktu yang 
singkat, masyarakat kota Surakarta mudah untuk terbakar emosi. melakukan kekerasan seperti penjarahan maupun pembakaran asset-aset mili masyarakat etnis.

Menurut Sartono Kartodirdjo, pada tahun 1913 dicatat sebagai "lembaran terburam" dalam sejarah Indonesia, sejauh menyangkut kerusuhan-kerusuhan anti Cina (Rahardjo, 2005:104). Puncaknya pada Tragedi Mei 1998. Konflik etnis Tionghoa dan Jawa terus terjadi dan berulang yang biasanya disertai amukan massa (pembakaran, penjarahan, perkosaan dengan kekerasan). Sentiment rasial yang digunakan dalam Peristiwa Mei 1998 merupakan salah satu faktor yang menyebabkan meledaknya kerusuhan. Faktor lain yang melatar belakangi peristiwa Mei 1998 tidak lain merupakan imbas dari krisis ekonomi, permasalahan di bidang politik dan hukum, serta menurunnya tingkat kepercayaan masyarakat terhadap pemerintah.

Krisis moneter yang melanda seluruh negara di bagian Asia turut menyumbangkan kekacauan dalam sektor ekonomi. Nilai tukar rupiah kemudian merosot dengan cepat dan tajam dari rata-rata Rp 2.450 per dollar AS Juni 1997 menjadi Rp 13.513 akhir Januari 1998. Kenaikan kurs Dollar sepanjang tahun 1997 hingga 1998 berdampak langsung kepada penurunan devisa secara drastis. Melihat situasi ekonomi yang semakin tidak terkendali, pemerintah Indonesia mencoba meminta bantuan IMF untuk memulihkan kepercayaan pasar dan menstabilkan rupiah.

Setelah krisis moneter, pelbagai masalah mulai menampakkan diri dengan harga kebutuhan pokok menjadi tinggi dan barang yang sulit di dapat, pengangguran bertambah banyak serta angka putus sekolah mulai meningkat, masyarakat mulai gelisah dan menggugat. Di sisi lain, mahasiswa, sebagai bagian dari masyarakat, ikut terimbas. Dan rupanya, kali ini mereka tidak sekadar berempati, melainkan juga secara nyatanyata mereka sendiri ikut tertimpa pengaruh buruk itu. Belasan ribu dari mereka yang tersebar di berbagai perguruan tinggi negeri dan swasta tak terkecuali yang kuliah di luar negeri terancam tidak dapat melanjutkan studi akibat melambungnya harga kertas, alat-alat praktikum, biaya kuliah, dan biaya hidup sehari-hari yang terjadi secara tiba-tiba (Zamroni dan Andin, 1998).

Pada akhir pemerintahan Orde Baru di bawah Presiden Soeharto kepercayaan masyarakat kepada pemerintahan semakin merosot sampai titik yang sangat rendah. Merosotnya kepercayaan masyarakat terhadap pemerintah itu semata-mata tidak datang secara mendadak karena krisis ekonomi, tetapi berlangsung dalam waktu yang sangat lama, setahap demi setahap yang disebabkan oleh adanya penyimpangan-penyimpangan dan kekurangan-kekurangan dalam bidang non ekonomi.

Memasuki bulan Maret hingga pertengahan bulan Mei 1998 aksi mahasiswa menuntut reformasi semakin bertambah. Dalam Kota Surakarta terhitung lebih dari 25 kali gerakan mahasiswa berlangsung di kampus UNS Kentingan maupun UMS Pabelan. Situasi demonstrasi di kedua kampus acap kali memanas. Bentrokan antara mahasiswa aksi dengan aparat keamanan tidak terelakan.

Situasi semakin memanas dikala krisis ekonomi dan sosial melanda Indonesia. Pemerintah mengumumkan rencana kenaikan harga bahan bakar minyak (BBM), tarif dasar listrik (TDL), dan tarif angkutan. Respon negatif pun disuarakan di berbagai wilayah 
Indonesia. Memasuki sore hari setelah pemerintah mengumumkan kenaikan harga, kerusuhan meletus di medan dan sekitarnya.

Gerakan aksi demonstrasi nasional pada bulan Mei menunjukkan secara serentak 6 tuntutan reformasi sebagai agenda utama aksi. Adapun isi tuntutan reformasi, adili Soeharto dan kroni-kroninya, laksanakan amandemen UUD 1945, hapuskan dwifungsi ABRI, pelaksanaan otonomi daerah yang seluas-luasnya, tegakkan supremasi hukum, dan ciptakan pemerintahan yang bersih dari KKN.

Hingga puncaknya, gerakan aksi demokrasi yang menuntut pemerintahan orde baru di beberapa daerah di Indonesia mulai berbalik menjadi arena kerusuhan. Sentimen massa dalam proses terjadinya kerusuhan terbagi menjadi dua yaitu, terhadap pemegang sendirsendi ekonomi dan unsur-unsur yang dekat dengan kekuasaan. terhadap masyarakat minoritas khususnya etnis Tionghoa menjadi tidak terkendali.

Kerusuhan sosial yang terjadi pada bulan Mei 1998 mengakibatkan kerugian yang tidak terhitung baik materiil maupun non materiil. Penjarahan, kebakaran, pengrusakkan, pelemparan bom oleh massa yang membabi buta menghancurkan Kota Solo. Berbagai bangunan yang dianggap "berbau Tionghoa" di rusak, dibakar dan dijarah. Supermarket, plaza, gedung bioskop, hotel hancur dan mematikan sendi perekonomian masyarakat. Tak hanya itu, terminal bus Tirtonadi yang juga turut dilalap oleh si jago merah seolah-olah menjadi saksi bisu kebrutalan aksi massa ini. Transaksi-transaksi bisnis yang mewarnai kota ini menjadi macet. Kerugian finansial yang ditimbulkan diperkirakan mencapai sekitar empat setengah milyar lebih (Rp 457.534.945.000). Sebanyak 31 orang meninggal dunia, dan 16.000 orang kehilangan pekerjaan (Mulyadi dan Sudarmono, 1999). Sederet peristiwa ini telah menyisakan bayang-bayang ketakutan dan trauma pada warga. Berdasarkan latar belakang diatas maka rumusan masalah yang diambil adalah Bagaimana kronologi kerusuhan Mei 1998 di Kota Surakarta? Bagaimana dampak Konflik kerusuhan Mei 1998 di kota Surakarta?

\section{METODE PENELITIAN}

Penelitian ini dilakukan di kota Surakarta. Kota Surakarta merupakan salah satu kota yang mengalami kerusakan terparah dari kejadian Mei 1998. Adapun jangka waktu yang digunakan untuk melakukan penelitian yaitu pada bulan Desember 2018 sampai dengan Juni 2019. Penelitian ini merupakan penelitian kualitatif dengan menggunakan pendekatan etnografi. Teknik pengumpulan data menggunakan teknik wawancara, observasi dan dokumentasi. Untuk mengkaji data menggunakan triangulasi sumber. Sedangkan teknik analisis data menggunakan teknik analisis interaktif yang dimulai dengan pengumpulan data, reduksi data, penyajian data, dan penarikan kesimpulan. 


\section{HASIL DAN PEMBAHASAN \\ Kota Surakarta Tahun 1965-1998}

Konflik kerusuhan Mei 1998 tidak terlepas dari era pemerintahan orde baru. Pergantian tonggak kepemimpinan dari Presiden Soekarno ke Presiden Soeharto membawa pada perubahan sosial-ekonomi masyarakat. Diawal pemerintahan Presiden Soeharto, ia menghadapi hutang luar negeri sebesar $\$ 2.400$ juta, laju inflasi yang mencapai $20-30 \%$, kondisi infrastruktur yang berantakan, kapasitas produksi sektor industri dan ekspor yang menurun, penarikan pajak yang macet, hingga kenaikan bahan-bahan pokok yang drastis. Runtuhnya perekonomian Indonesia membawa jumlah penduduk miskin meningkat drastis.

Hingga periode ketiga pemerintahan Presiden Soeharto, sepertiga jenis pekerjaan masyarakat Kota Surakarta tercatat sebagai buruh, baik buruh industri maupun buruh bangunan. Jumlah buruh industri dan bangunan mendominasi jumalah angkatan kerja sebesar 85.279 orang atau 30.45\% di tahun 1976, angka ini terus meningkat hingga tahun 1996 menjadi 142.024 atau $37.79 \%$. jumlah angka tersebut bisa saja naik jika melihat banyaknya oenduduk yang berada pada kelompok lain-lain. Jumlah kelompok pekerja lain-lain menjadi mayoritas, tahun 1976 tercatat berjumlah 139.972 orang atau sama dengan 50.28\%, tahun 1986 mengalami penurunan drastis menjadi 131.768 atau $39.52 \%$, tahun 1986 mengalami kenaikan kembali menjadi 140.024 atau merangkak hingga $37.79 \%$. mereka yang termasuk dalam kelompok pekerja lain-lain merupakan orang yang sementara tidak bekerja ataupun orang yang sedang mencari pekerjaaan (BPS Kota Surakarta, 1986).

Dari segi politik, kondisi politik Kota Surakarta tidak jauh berbeda dengan daerahdaerah lain di Indonesia. Kondisi politik di Kota Surakarta mengalami pasang surut setelah pergantian kepemimpinan. Mengacu kepada hasil pemilu tahun 1955 di Kota Surakarta mengeluarkan Partai Nasional Indonesia (PNI), Partai Komunis Indonesia (PKI), Masyumi dan Nahdatul Ulama (NU) sebagai partai politik yang memiliki kekuatan yang dominan. Pada pemilu tahun 1955 di Surakarta PKI menjadi partai dengan jumlah perolehan suara yang terbesar. PKI memperoleh 70.808 suara atau setara dengan 57.26\%. tempat kedua diraih oleh PNI dengan jumlah suara 37.144 suara atau 30\%. Masyumi memperoleh 13.733 suara atau $11.10 \%$. sedangkan NU menjadi partai dengan perolehan suara terkecil sebesar 1.998 suara atau $1.61 \%$. PKI berhasil memenangkan pemungutan suara di seluruh wilayah kecamatan di Kota Surakarta (Mulyadi dan Sudarmono, 1999).

Memasuki tahun 1980, Kota Surakarta tidak luput dari konflik antar masyarakat. Peristiwa 19 November 1980 yang diakibatkan berjalan selama dua hari. Akar masalah konflik ini bermula oleh kejadian tabrakan lalu-lintas di jalan sekitar Warung Pelem pada 19 November 1980, antara pipit (Jawa) pelajar Sekolah Guru Olahraga (korban) dan kicak, seorang pemuda Tionghoa. Kemudian disusul dengan pemukulan pipit oleh kicak (Rustopo, 2007:100-101). Peristiwa ini dengan berkembang cepat menjadi kerusuhan massal di Kota Surakarta terutama yang terdapat pertokoan milik orang-orang Tionghoa. Selain merusak dan membakar toko-toko, massa juga melakukan aksi penjarahan.

Selama masa pemerintahan orde baru, pemerintah terus mencoba untuk meredam pergerakan mahasiswa dan pemuda di Surakarta. Dimulai dari dibuatnya KNPI sebagai wadah bagi organisasi kemahasiswaan dan pemuda. Ditingkat bawah pemerintah 
membubarkan organisasi-organisasi seperti DEMA yang memiliki konsep sebagai student government. Keberadaan KNPI sebenarnya mampu menampung seluruh aspirasi mahasiswa. Hanya saja kepemimpinan KNPI diisi oleh orang-orang yang berasa dari partai Golkar. Sehingga kegiatan-kegiatan yang dilaksanakan KNPI terkadang tidak mencerminkan organisasi mahasiswa dan pemuda (Jurdi, 2012)

Menjelang akhir tahun 70an hanya sedikit mahasiswa yang mau bergabung dalam aktivitas gerakan-gerakan melawan resistensi negara. Mahasiswa yang tergabung pada aktivitas ataupun gerakan merupakan mereka yang memiliki kesadaran tinggi atas apa yang dialaminya. Kondisi ini semakin diperparah dengan tindakan represif terhadap aktivis mahasiswa.

Pertemuan-pertemuan kelompok menjadi sangat sulit. Perkumpulan yang melibatkan lebih dari 5 orang akan mengundang kecurigaan. Setiap pergerakan ataupun aktivitas yang dilakukan akan dicurigai aparat. Terlebih jika menyangkut diskusi buku-buku yang dilarang beredar dan dibaca seperti buku Pramoedya Ananta Toer. Membaca tulisan-tulisan dari Pram akan mendapat stigma pki yang merupakan musuh dari orde baru. Sehingga tidak jarang kegiatan diskusi buku yang dilakukan mahasiswa dibubarkan oleh polres.

Memasuki tahun 1997 gelombang aksi mahasiswa maupun aktivis mulai memanas. Aksi demonstrasi membela upah buruh dan meminta pertanggungjawaban ngara atas keadaan ekonomi. Ditengah situasi yang memanas muncul tokoh-tokoh nasional yang mendukung gerakan reformasi salah satunya ialah Amin Rais. Disamping itu aktivis mahasiswa juga ikut merapatkan barisannya melalui kegiatan-kegiatan SMID maupun PRD. Penambahan jumlah aktivis muncul setelah adanya pergerakan kedung ombo.

Maraknya permasalahan negara dijadikan sebagai suatu momentum bagi mahasiswa untuk berjejaring dengan sesama mahasiswa di tingkat kota. Mahasiswa membangun sebuah aliansi yang menjadi wadah untuk berkumpul dan menjalankan aksi. Hasil dari pertemuan antar mahasiswa yaitu dilakukannya demo secara rutin satu minggu dua kali di hari selasa dan jumat di kampus UNS.

Hingga terjadinya kerusuhan Mei 1998, tercatat kurang lebih 30 kali demonstrasi dilakukan di kampus UNS Kentingan, Kampus UMS Pabelan, dan kampus perguruan tinggi swasta lainnya. Mahasiswa bersama-sama dengan pelajar dan pemuda lainnya terus melakukan aksi menuntut adanya perubahan. Memasuki bulan Mei 1998, tuntutan mahasiswa memiliki fokus untuk melakukan reformasi total. Slogan-slogan aksi seperti 'Reformasi atau Mati' mulai di dengungkan di seluruh perguruan tinggi di Indonesia.

Penurunan nilai mata uang Thailand baht terhadap dollar AS, dari 24,7 baht per dollar AS menjadi 29,1 baht per dollar AS. Puncak krisis moneter di Thailand ditandai dengan penutupan 56 dari 58 lembaga keuangan utama pada 8 Desember 1997 (Habibie, 2006). Krisis penurunan nilai mata uang bath juga diikuti oleh beberapa negara di Asia Tenggara dan Asia Timur lainnya, seperti Filipina, Malaysia, Indonesia hingga Korea Selatan.

Krisis moneter menyebabkan peningkatan jumlah pengangguran terbuka, dari, 4,68 juta orang pada tahun 1998 menjadi 5,46 juta orang di tahun 1998. Demikian pula dengan jumlah setengah pengangguran yang meningkat dari 28,2 juta jiwa pada 1997 menjadi 32,1 juta jiwa pada 1998 (Habibie, 2006). Pertambahan jumlah penganggur dan setengah 
penganggur mengakibatkan penurunan pendapatan masyarakat yang akan mengakibatkan krisis sosial di berbagai bidang. Krisis sosial apabila dibiarkan secara terus menerus akan mempengaruhi keamanan masyarakat. kenyataan ini membuat sebagian masyarakat resah dan takut akan kenyataan yang menimpa hidup mereka.

Memasuki bulan Mei 1998, aksi mahasiswa menuntut penurunan Presiden Soeharto semakin memanas. Peningkatan jumlah aksi demontrasi mulai meningkat di berbagai perguruan tinggi. Jumlah peserta aksi juga turut mengalami peningkatan. Elemen masyarakat turut bersatu dengan mahasiswa dalam aksi demonstrasi. Dalam beberapa kesempatan, tak jarang aksi diwarnai bentrok dengan aparat keamanan. Sehingga banyak korban luka-luka yang harus dilarikan ke rumah sakit terdekat. Aksi kekerasan yang dilakukan oleh aparat keamanan mulai menyulut ketegangan dalam masyarakat. sentimen masyarakat dengan aparat kian bertambah.

\section{Kerusuhan 14-15 Mei 1998}

Tanggal 14 Mei 1998, mahasiswa dari Universitas Muhammadiyah Surakarta melakukan aksi demonstrasi. Persiapan aksi demonstrasi mahasiswa yang dilakukan di Kampus UMS Pabelan dimulai sejak Pk 07.30 pagi. Kampus UMS bagian selatan dan utara mulai diblokade oleh aparat keamanan. Blockade ditujukan untuk memisahkan mahasiswa yang berada di dalam kampus dengan massa yang berkumpul di luar kampus. Perlahan demi perlahan mahasiswa mulai berkumpul di depan kampus memenuhi sisi kanan dan kiri jalan hingga area sekitar jembatan. Melihat adanya kerumunan mahasiswa yang mulai memenuhi jalan, aparat meminya mahasiswa untuk masuk kembali ke dalam area kampus (Jusuf, dkk, 2008).

Memasuki Pk. 11.00 mahasiswa melakukan shalat dhuhur untuk mendoakan mahasiswa Trisakti yang gugur. Setelah itu acara dilanjutkan dengan orasi-orasi. Suasana semakin lama menjadi sangat emosional dari kedua pihak. Aksi dorong-mendorong tidak dapat dihindari. Benturan pun pecah, berdasarkan laporan aksi ini dipicu oleh para provokator yang melempar benda kearah polisi dari dalam kampus (Tim Gabungan dalam Purdey, 2013). Aksi menjadi semakin memanas dengan balasan berupa gas air mata mata yang ditembakkan aparat mnuju barisan mahasiswa. Aksi saling membalas antara mahasiswa dan aparat semakin menjadi. Aparat terus melakukan serangan-serangan untuk menghalau massa aksi keluar dari area kampus. Massa aksi yang tidak memiliki alat pertahanan untuk melawan aparat akhirnya berlarian hingga area kampus. Suhu demonstrasi menjadi memanas dan semakin lama berubah beringas. Frekuensi pelemparan terus meningkat sehingga menciptaan hujan batu. Melihat situasi yang tidak terkontrol memaksa aparat keamanan melepaskan tembakan peluru karet dan gas air mata.

Memasuki siang hari, bibit-bibit kericuhan mulai terbentuk ketika aparat mencoba untuk menahan massa keluar dari area kampus UMS. Massa yang berhasil lolos dari kartasura terus bergerak menuju pusat kota dan melakukan perusakan. Jumlah massa perusakan yang bergerak tidak terlalu banyak. Disamping pergerakan massa yang mulai memasuki kota, massa tambahan mulai berkerumun dimulai sekitar pertigaan lampu merah jalan Slamet Riyadi dan jalan Ahmad Yani. Jumlah massa semakin lama-semakin bertambah 
bersamaan dengan waktu kepulangan anak-anak sekolah. Massa mulai memadat sepanjang jalan Slamet Riyadi terutama di depan SMP batik dan gedung bekas SGPLB hingga depan Markas Korem. Kerumunan massa bahkan sudah menutup jalur angkutan umum (Mulyadi dan Sudarmono, 1999).

Menuju pertigaan pasar sidodadi kleco, terlihat kepulan asap pekat hasil pembakaran ban bekas. Setelah melewati Pasar Kleco massa mulai melempari showroom mobil. Ketika massa sudah berada di depan Showroom Timor terdengar suara "hancurkan". Suara tersebut berasal dari orang-orang yang sebelumnya sudah berada di sekitar showroom Timor. Tak lama, anak-anak remaja yang membawa tas kain dengan serentak melemparkan batu kearah showroom Timor. Aksi ini memikat massa lain untuk melakukan hal serupa. Massa yang ikut dalam perusakan Showroom timor bersorak gembira layaknya telah melepas beban akibat kekecewaan dan kemarahan yang tersalurkan.

Target pertama massa merupakan simbol-simbol kekuasaan termasuk kelompokkelompok yang dekat dengan kekuasaan yang dinilai tidak "absah" secara prosedural (Rahadi, 1998). Sehingga Massa merusak rumah pameran mobil timor yang dimiliki oleh anak kelima Soeharo, Tommy Soeharto. Selain itu massa juga merusak rumah dinas kapolwil serta kantor perbankan tertentu.

Target kedua, massa menyalurkan amarahnya terhadap simbol-simbol kesenjangan sosial. Massa melakukan perusakan terhadap harta benda yang menonjolkan kesenjangan sosial antara kelompok bawah dengan kelompok atas, maupun terhadap pelaku politik dan ekonomi. Hal ini tercermin dari tindakan massa yang menghancurkan dan membakar kendaraan roda dua ataupun empat, pabrik-pabrik, perusahaan-perusahaan, toko-toko, bangunan-bangunan atau fasilitas lain berasal dari pemerintah maupun kelompok swasta milik keturunan tionghoa (Rahadi,1998).

Tahap terakhir. jaminan keamanan dan hukum mulai melemah. Massa yang dimanfaatkan oleh kelompok-kelompok tertentu mulai melampiaskan kecemburuan sosial dengan mengambil harta kekayaan milik orang lain melalui cara "premanisme" (Rahadi, 1998).

Memasuki siang hari massa tenang yang tidak berbahaya secara tidak disadari disusupi oleh orang luar. Mereka mencoba untuk membakar emosi massa dengan melakukan provokasi-provokasi. Terlihat di sekitar Purwosari beberapa orang menaiki motor dan berhenti di depan ruko-ruko. Orang-orang itu memulai merusak etlase toko dan memberikan komando bagi massa untuk menjarah. Barang yang sudah diambil dari dalam toko dikumpulkan dan dibakar.

Kelompok perusuh pada kerusuhan Mei 1998 layaknya pemandu. Mereka memberikan arahan kepada massa aktif untuk merusak toko-toko yang dipilih. Pada aksinya, kelompok perusuh memberikan gambaran awal dengan merusak dan menjebol toko-toko kepada massa aktif. Kemudian dengan sendirinya massa aktif mulai mengikuti perilaku kelompok perusuh.

Dokumentasi Solopos merekam massa yang melakukan perusakan tidak menunjukan raut kemarahan melainkan ekspresi lepas dari tekanan. Diyakini bahwa massa ini termasuk massa pasif yang berubah menjadi massa aktif. Mereka bukanlah bagian dari provokator 
melainkan hanya sebagai penggembira. Ichwan sendiri melihat langsung provokator yang pertama kali mencoba membakar emossi massa dan melemparkan benda keras untuk merusak di Purwosari. Provokator mencoba untuk menghancurkan kaca etalase. Sehingga bendabenda yang terjual terlihat langsung dari depan. Etalase yang rusak memudahkan massa untuk melakukan penjarahan. Ketika satu orang memulai untuk melakukan penjarahan, maka massa lain menjadi tertarik mengikuti perilaku menjarah. Perilaku menjarah menular bagaikan domino. Ketika melihat ada orang yang dengan bebas mengambil dengan mudah barang yang bukan miliknya, kemungkinan besar ada orang lain yang tergiur dan mengikuti perilaku tersebut. Jika diperhatikan kembali ciri-ciri orang yang pertama kali memprovokasi dan merusak di Purwosari, ciri-ciri tersebut mirip seperti tentara. Provokator bergerak dalam kelompok kecil. Pergerakan mereka sangat rapih dan terorganisir.

Sementara itu massa yang berjalan menuju jalan Urip Sumoharjo terbelah menjadi dua arah. Beberapa massa memilih menyusuri selatan Pasar Gede hingga perempatan lampu merah menuju Loji Wetan. Sedangkan massa lainnya menyusuri sepanjang jalan Urip Sumoharjo dengan merusak dan melempari batu ke berbagai bangunan yang ada. pembakaran juga terjadi di jalan Urip Sumorharjo. Dua buah kendaraan yang terpakir di depan hotel trio menjadi sasaran pembakaran massa.

Kelompok massa yang berada di jalan Urip Sumoharjo kembali terpecah mengikuti perempatan jalan Sultan Syahrir dan Jalan Kapten Tendean. Massa menyusuri jalan raya hingga ke arah Pasar Legi. Massa melakukan kembali aksi perusakan dengan melempar batu ke arah bangunan pasar Legi hingga perempatan Stasiun Balapan.

Terhitung pada tanggal 15 Mei 1998, roda pemerintahan dan ekonomi dapat dinyatakan lumpuh total. Banyak toko-toko yang memilih untuk menutup tokonya. Pusatpusat perbelanjaan seperti matahari Songosaren, Beteng Plaza, Purwosari Plaza, dan Ratu Luwes, Sami Luwes hancur dilalap api. Sehingga pasar tradisional menjadi salah satu jalan untuk melayani kegiatan perekonomian warga kota Surakarta.

Aksi perusakan dan pembakaran di hari kedua terus berjalan hingga pukul 18.30. untuk mengantisipasi aksi kerusuhan melebar, aparat keamanan kembali memberlakukan jam malam. walaupun hari pertama meletusnya kerusuhan dilakukan jam malam. tetapi pemberlakuan jam malam belum terlalu efektif. Hanya di daerah-daerah tertentu jam malam berlangsung dengan baik. Sementara di tempat lain aksi perusakan, penjarahan dan pembakaran masih terus berlanjut.

\section{Pasca Kerusuhan Mei 1998}

Kerusuhan yang melanda Kota Surakarta menimbulkan berbagai kerugian yang besar dari ekonomi, sosial hingga psikologi. Seluruh masyarakat Kota Surakarta menjadi korban akibat kerusuhan ini. Kehancuran terlihat dari berbagai sudut kota. Toko-toko, supermarket, perkantoran hingga rumah tinggal banyak yang dirusak hingga dibakar. Berbagai fasilitas umum layaknya pos polisi, rambu lalu lintas sampai telepon umum dihancurkan oleh massa. bangkai mobil dan sepeda motor yang terbakar dapat terlihat di sepanjang jalan.

Setelah 2 hari pasca kerusuhan ditemukan korban-korban yang ikut terbakar di dalam bangunan toko dan pasar swalayan. Jumlah korban yang ditemukan sebanyak 3 jenazah, 14 
korban meninggal ditemukan di dalam gedung Toserba Ratu Luwes Pasar legi, 19 korban lainnya ditemuan di dalam toko sepatu Bata. Berdasarkan kesaksian salah seorang anggota UPGD Crisis Center PWI Solo (dalam Mulyadi dan Soedarmono, 1999), 19 jenazah ditemukan dengan keadaan berkelompok-kelompong dan saling menindih satu sama lain. Lokasi penemuan korban berada di dekat sumur belakang toko, tangga besi toko yang runtuh dan sisanya berada di kamar mandi toko. Keadaan korban saat ditemukan sudah tidak lengkap. Beberapa bagian tubuh sudah terbakar.

Kerusuhan yang memakan waktu selama dua hari mengakibatkan kerugian meteral sebanyak Rp. 457.534.954.000,- kerugian terbesar ditanggung oleh plaza dan supermarket senilai Rp. 189.637.500.000,- Diikuti dealer dan showroom dengan total kerugian sebesar Rp. 98.783.700,-. Selain itu kerugian juga ditanggung oleh toko-toko, pabrik, bus, hotel hingga restoran. Kerusuhan 14-15 Mei 1998 juga berpengaruh besar dalam berputarnya roda perekonomian. Pasca kerushan tidak ada lagi pusat perbelanjaan ataupun toserba yang beroperasi. Pusat perbelanjaan seluruhnya hanya bisa diakses melalu pasar tradisional. Dari sisi kehidupan sosial, kerugian memiliki dampak psikologis traumatis bagi sebagian masyarakat yang menjadi korban. Selain itu akibat kerusuhan ini banyak masyarakat yang dengan terpaksan menjadi pengangguran. Hal ini diakibatkan tempat mereka bekerja dirusak ataupun dibakar.

Kondisi ekonomi Kota Surakarta pasca kerusuhan 14-15 Mei 1998 dinyatakan hampir lumpuh total. Roda perekonomian tidak bisa bergulir dengan baik. Seluruh fasilitas ekonomi seperti bank, toko swalayan hingga toko-toko tradisional tidak beroperasi. Keputusan untuk menutup seluruh gerai-gerai didasarkan alasan keamanan. Pasca kerusuhan beredar berbagai issu akan terjadinya kerusuhan susulan. Ketakutan-ketakutan ini berimbas juga kepada sejumlah pasar tradisional yang biasanya beroperasi selama 24 jam menutup, pasca kerusuhan hanya beroperasi setengah hari. Ditengah-tengah keadaan ekonomi kota yang lumpuh, pasar tradisional menjadi jalan keluar bagi masyarakat kota. Selama beberapa hari masyarakat hanya bisa bergantung kepada pasar tradisional. Walaupun harga kebutuhan pokok pasca kerusuhan melonjak tinggi. Penutupan toko-toko tradisional disebabkan kondisi bangunan yang dihancurkan selama kersuhan, sebagian lagi pemilik toko yang merasa takut akan dijarah jika membuka tokonya.

Pasca kerusuhan, PMS membangun posko-posko yang tersebar di 5 kecamatan dijaga oleh beberapa petugas yang siap membantu warga yang datang. Bagi warga yang mengalami kerugian baik dari segi materi hingga psikis, maka akan di data nama, alamat, jenis kerugiannya dan bantuan apa yang diharapkan. PMS juga membantu warga untuk mengurus pembuatan surat-surat dan akte yang hilang saat kerusuhan. Selain itu PMS juga memberikan santunan bagi keluarga korban selama 3 bulan. Santunan diberikan untuk kepala keluarga sebesar 200 ribu dan untuk istri beserta anak-anak diberikan masing-masing sebesar 100 ribu. Apabila satu keluarga memiliki 2 orang anak. Maka PMS akan memberikan dana sebesar Rp. 500.000,- dengan rincian Rp. 200.000,- untuk kepala keluarga dan Rp. 300.000,- untuk istri dan kedua anaknya. Pemberian dana diberikan kepada keluarga yang saat kerusuhan mengalami kebakaran yang menghabiskan seluruh assetnya ataupun masyarakat yang assetnya dijarah dan dirusak habis oleh massa. 
Selain itu PMS juga memberikan layanan lain, korban kerusuhan Mei 1998 dapat memanfaatkan fasilitas yang disediakan dalam rangka rehabilitasi pasca kerusuhan. Dalam kerjanya PMS membantu seluruh masyarakat yang membutuhkan bantuan dalam urusan administrasi hingga pelayanan psikologis.

PMS memiliki program untuk memperiapkan masyarakat Kota Surakarta untuk kembali bekerja ataupun membuka usaha. Masyarakat diberikan waktu 3 bulan untuk recovery. Apabila masyarakat merasa sudah siap kembali bekerja, mereka memiliki kesempatan untuk kembali ke PMS. Masyarakat yang sudah siap bekerja kembali akan dimbimbing Apabila masyarakat merasa belum siap untuk kembali bekerja, PMS memberikan santunan untuk 3 bulan kedepan. Bagi masyarakat yang siap bekerja akan diberikan bantuan sebesar 7 juta. Pemberian bantuan disalurkan oleh salah satu Lembaga keuangan Sarana Surakarta Ventura.

Bantuan lain bagi masyarakat Kota Surakarta disalurkan melalui Gereja Kristen Indonesia (GKI) Sangkrah. Merespon peristiwa Kerusuhan yang terjadi secara massif di Kota Surakarta, GKI Sangkrah membuka penggalangan dana untuk membantu korban kerusuhan. Penggalangan dana dilakukan secara terus-menerus sebagai bentuk kepedulian gereja terhadap masyarakat Kota Surakarta. GKI Sangkrah mampu membantu kurang lebih $100 \mathrm{KK}$ yang tersebar di seluruh Kota Surakarta. Dalam hal ini gereja tidak hanya membantu jemaat GKI yang menjadi korban, tetapi seluruh masyarakat yang membutuhkan akan dibantu oleh gereja. Bantuan yang diberikan berupa sejumlah uang tunai senilai 4 Juta. Adapun jumlah bantuan yang diberikan tergantung dengan kerusakan yang diderita.

Salah satu dampak dari kerusuhan Mei 1998 ialah beban psikologis bagi korban. Tekanan psikologis dirasakan bagi korban yang kehilangan harta benda, korban yang melihat langsung kebringasan massa hingga korban yang kehilangan anggota keluarganya. Beban psikologis yang diderita korban berpengaruh terhadapan kehidupannya.

Selama kerusuhan berlangsung tercatat sebagian kecil masyarakat mengungsi ke daerah lain seperti ke Pulau Batam, Klaten, Salatiga hingga ke luar negeri. Dalam laporan Kompas 21 Mei 1997, selama enam hari pasa kerusuhan terdapat 14.000 orang yang menyebrang ke Singapura melalui terminal penyebrangan antar pulau. Masyarakat secara bertahap meninggalkan daerahnya untuk berlindung dari kemarahan massa. masyarakat rela berpergian hingga ke desa-desa ataupun hanya menitipkan keluarganya ke tempat orang lain yang tinggal di daerah yang aman.

Passca kerusuhan Mei 1998, sebagian kecil dari korban sudah mulai pulih dari rasa trauma. Namun sebagian lain dari korban hingga kini masih belum dapat pulih dengan sempurna dari trauma yang dirasakan. Ketakutan-ketakutan pasca kerusuhan Mei 1998 masih terus menghampiri apabila mendengar kabar maupun berita bahwa akan ada keramaian. Trauma yang dialami korban sudah terjadi selama bertahun-tahun. Sebagian korban kerap kali memikirkan hal terburuk yang terjadi jika terdapat keramaian yang melebihi batasnya.

Dalam beberapa kasus beberapa korban masih belum bisa pulih dari rasa trauma akibat peristiwa Mei 1998. Walaupun secara fisik korban terlihat seperti orang pada umumnya. Tetapi dari segi psikis, korban belum bisa pulih seperti keadaan sebelumnya. Hal ini terlihat jika tersebar isu-isu yang tidak dapat dikonfirmasi terkait akan terjadi kerusuhan 
kembali. Korban akan merespon dengan sikap cemas. Perasaan takut menghantui jika terjadi hal buruk untuk kedua kalinya. Sehingga untuk mencegah kerusuhan-kerusuhan yang akan terjadi, korban selalu siap untuk menyelamatkan diri sewaktu-waktu. Belajar dari kerusuhan 1998, beberapa korban selalu membawa mata uang asing dan passport. Tanda-tanda dari sikap waspada korban menandakan bahwa korban belum sepenuhnya pulih dari rasa trauma kerusuhan Mei 1998.

Jika berkaca dari aksi demonstrasi yang terjadi dalam beberapa tahun belakangan. Aksi demonstrasi yang berbau agama serta menarik massa yang besar dan tersebar di beberapa daerah-daerah. Melihat pergerakan dari aksi-aksi demonstrasi tidak jarang menimbulkan kecemasan bagi korban. Kecemasan timbul akibat kerusuhan Mei 1998. Jika dilihat kembali kronologi awal kerusuhan Mei 1998 bermula dari demonstrasi yang melibatkan jumlah massa yang cukup besar. Kemudian kelompok perusuh datang dengan menyamar menjadi bagian dari massa aksi. Mereka memainkan emosi massa hingga melakukan aksi-aksi perusakan yang ditujukan kepada pihak-pihak tertentu. tidak beberapa lama aksi perusakan menyebar hingga ke daerah pemukiman masyarakat.

Diantara korban Mei 1998 yang menyatakan dirinya pulih dari trauma, beberapa korban lainnya masih merasakan trauma yang mendalam. Dalam beberapa pertemuan diskusi yang dilakukan komunitas Jejer Wadon bersama korban Mei 1998 khususnya perempuan, melalui komunikasi yang dilakukan ditemukan berbagai kisah masing-masing korban. Jika dikatakan, semakin tinggi intensitas diskusi yang mengulang kembali ingatan-ingatan Mei 1998 akan membuat korban menjadi seperti semula. Namun kenyataannya tidak seperti yang dibayangan. Beberapa kali korban menyalurkan cerita-cerita masa lalu dan traumanya, korban akan kembali menjadi sensitif. Kesedihan terus menghampiri korban manakala korban mengingat peristiwa-peristiwa yang dilewati pada kerusuhan Mei 1998. Trauma tidak sepenuhnya hilang dari diri korban. keadaan tersebut turut dirasakan secara langsung oleh Ibunda dari Gilang hingga Ayah dari Joko. Sudah berulang kali kedua korban memberikan testimoni di depan umum, tetap saja keluarga terus merasakan kesedihan yang mendalam.

Trauma yang dirasakan oleh korban pasca kerusuhan Mei 1998 ialah trauma ketakutan, trauma kehilangan harta benda dan trauma kehilangan anggota keluarga. Pasca kerusuhan Mei 1998 Kota Surakarta memang tidak memiliki unit-unit khusus dan tersebar di seluruh kota untuk dalam menangani trauma korban. Pergerakan identifikasi korban selama kerusuhan dilakukan secara mandiri oleh perkumpulan masyarakat yang dibantu relawanrelawan. Mereka mencoba untuk mencatat ke berbagai tempat, melihat jenis kerusakan, mengidentifikasi korban hingga memberikan bantuan bagi korban secara mandiri.

Hingga saat ini masyarakat ataupun korban memaknai kejadian Mei 1998 dengan berbagai macam emosi. Tidak menutup mata bahwa sampai saat ini masih ada korban yang memendam perasaan marah ataupun ketakutan atas apa yang dialaminya pada tahun 1998. Perasaan emosi yang berkembang dan bertahan dapat menyebabkan terganggunya aktivitas individu. Korban akan menjadi sensitif dibandingkan masyarakat lain. Namun dibalik perasaan maupun emosi yang meliputi korban, beberapa bagian dari korban mei 1998 sudah berada dalam tahap memaafkan ataupun berdamai dengan diri sendiri. 
Melalui refleksi kedua korban Mei 1998 diketahui bahwa pasca Mei 1998 korban mulai menerima kenyataan bahwa kejadian kerusuhan Mei 1998 merupakan bagian dari perjalanan hidup. Korba memiliki pendirian bahwa kerusuhan Mei 1998 merupakan konflik yang dikehendaki Yang Maha Kuasa. Maka sebagai umatnya, manusia dinilai sanggup untuk melewati cobaan yang diberikan. Dibalik ujian dari Yang Maha Kuasa terdapat berkat yang tersimpan.

\section{PENUTUP}

Kronologi peristiwa kerusuhan Mei 1998 tidak bisa dipandang sebagai kejadian yang spontan. Kerusuhan Mei 1998 dipengaruhi oleh situasi politik, ekonomi, dan sosial yang terjadi sebelumnya. Hingga menjelang tanggal 14 Mei 1998, santer terdengar berbagai rumor bahwa akan terjadi sesuatu di Kota Surakarta. Pagi hari di tanggal 14 Mei 1998, Demonstrasi dan aksi solidaritas atas meninggalnya mahasiswa di Universitas Trisakti dilakukan di Universitas Muhammadiyah Surakarta. Aksi demonstrasi dimulai dengan situasi cair. Peserta aksi berorasi mengenai tuntutan-tuntutan kepada pemerintah.

Keadaan berubah menjelang siang hari. dengan jumlah massa yang semakin lama semakin bertambah, situasi terasa menegang. situasi berubah menjadi semakin kacau ketika seseorang dari barisan mahasiswa yang melempar suatu benda kearah aparat. Aksi saling membalas antara aparat dan mahasiswa terjadi dengan cepat. Disisi lain massa yang melihat tindakan keras aparat mulai berlari ke segala arah. Kekacauan ini mulai dimanfaatkan oleh provokator untuk membakar emosi massa. Teriakan-teriakan reformasi mulai digaungkan. Aksi perusakan dimulai dengan target simbol-simbol kekuasaan hingga simbol-simbol kesenjangan sosial.

Provokator mencoba untuk merubah massa pasif menjadi massa aktif. Massa yang terprovokasi mencoba menyalurkan emosinya dengan melakukan perusakan, penjarahan, hingga pembakaran. Semua dilakukan secara spontan. Pada awalnya massa mulai melakukan perusakan di jalan-jalan arteri Kota Surakarta seperti Jalan Slamet Riyadi, Urip Sumoharjo. Kemudian massa mulai berpencar dan merusak hingga ke daerah pemukiman warga. Aksi kerusuhan ini terus berlanjut selama dua hari.

Kerusuhan yang tercipta di kota Surakarta melibatkan berbagai pihak khususnya kelompok perusuh, massa pasif, massa aktif hingga aparat keamanan. Beragam kepentingankepentingan bermain dalam porsinya. Kelompok perusuh memiliki kepentingan untuk menghancurkan kota surakarta. Dalam aksinya kelompok perusuh menggunakan massa pasif yang saat itu berada di sekitar titik konflik untuk mengikuti gerakan aksi amuk massa. Tanpa sadar massa pasif kemundian berubah menjadi massa aktif yang melakukan aksi perusakan, penjarahan hingga pembakaran. Pihak lain yang turut tanpa sengaja melancarkan proses kerusuhan ialah aparat keamanan. Kelonggaran-kelonggaran yang tercipta saat kerushan menjadi celah bagi kelompok perusuh dan massa aktif untuk menjalankan kepentingannya. 
Pasca kerusuhan Mei 1998 masyarakat tidak hanya mengalami kerugian dari segi harta benda, melainkan menimbulkan ketakutan bagi para korban. Beberapa korban mengalami trauma akibat melihat dan merasakan secara langsung kebrutalan yang dilakukan. Kerusuhan Mei 1998 secara tidak langsung membawa perubahan dalam kehidupan masyarakat terkhusus bagi korban. Kerusuhan Mei 1998 menghancurkan sendi-sendi ekonomi kota. Beberapa tempat usaha milik masyarakat menjadi sasaran amuk massa. Hingga pemilik usaha terpaksa harus kembali untuk membangun usahanya dari awal. Dari segi sosial pasca kerusuhan Mei 1998, berbagai masyarakat memutuskan untuk mengungsi ke daerah lain yang jauh dari konflik. Keputusan ini diambil setelah mempertimbangkan sisi keselamatan korban. Melihat sisi Psikologis pasca kerusuhan, banyak korban yang mengalami trauma akibat melihat langsung keganasan yang terjadi selama kerusuhan berlangsung. Hingga saat ini beberapa korban sudah dinyatakan pulih dari trauma yang dialaminya. Korban menerima kerusuhan Mei 1998 menjadi bagian hidup yang harus dijalani. Namun tidak menutup mata bahwa sebagian lain masih merasakan trauma serta ketakutan-ketakutan tersendiri lepas dari kerusuhan Mei 1998.

\section{DAFTAR PUSTAKA}

Aspinall, E., Feith, H. dan van Klinken, G. 1999. The Last Days of President Suharto. Clayton. Vic.: Monash Asia Institute.

Barsamian, David dan Liem Sok Lan. 2008. Menembus Batas (Beyond Boundaries) Damai Untuk Semesta : Wawancara Oleh David Barsamian dan Liem Siok Lan. Jakarta

Benedict, Anderson. 2002. Imagined Communnities. Yogyakarta: Insist \& Pustaka Pelajar

Biro Humas Komisi Pemilihan Umum. 2000. Pemilu Indonesia Dalam Angka dan Fakta Tahun 1955-1999. Jakarta: KPU.

Booth, Anne, 2000. The Crisis of 1997-1999 and the Way Out: What are the Lessons of History?. lembaran Sejarah Vol 3 No. 1

Cohen, Bruce J., 1992. Sosiologi suatu pengantar. Jakarta: PT. Rineka Cipta

DN, Susilastuti. 2000. Kebebasan Pers Pasca Orde Baru. Yogyakarta: Jurnal Ilmu Sosial dan Politik Vol. 4 No. 2

Habibie, Bacharuddi Jusuf. 2006. Detik-detik yang Menentukan Jalan Panjang Indonesia menuju demokrasi, Jakarta: THC Mandiri

Hakim, Abdul Aziz. 2011. Negara Hukum dan Demokrasi Di Indonesia. Yogyakarta: Pustaka Pelajar

Harsutejo, 2010. Kamus Kejahatan Orba. Jakarta: Komunitas Bambu

James, kenneth dan Narngchar Akrasance. 1992. Aspek Fnansial Usaha Kecil dan Menengah, Studi Kasus Asean. Jakarta: LPES

Jurdi, Syarifuddin. 2012. Dinamika Politik Kaum Muda Indonesia: Dialektika Politik Nasional dan Lokal. Sosiologi Reflektif, Vol. 6 No. 2

Jusuf, Ester Indahyani. Dkk. 2008. Kerusuhan Mei 1998 Fakta, Data dan Analisa, Solidaritas Nusa Bangsa dan Asosiasi Penasehat Hukum dan Hak Asasi Manusia Indonesia

LP3ES, 1995. Bank Indonesia dalam kilasan sejarah bangsa. Jakarta: LP3ES

Lubis, Todung Mulya. 1993. In Search of Human Rights: Legal-Polotical Dilemas of Indonesia's New Order, 1966-1990. Jakarta: Gramedia

McDonald, H. 1980. Suharto's Indonesia. Blackburn, Australia: Fontana Books.

Milne, R.S. 1984. "Teknokrat dan Politik di Negara-negara Asia Tenggara”. Jakarta: Penerbit LP3ES. 